\author{
하번초형 혼파조합간의 건물수량, 사료가치 및 식생비율 비교연구 \\ 이중해* . 이인덕* . 이형석** \\ 충남대학교 농업생명과학대학 동물자원학부*, 우송정보대**
}

\title{
A Comparison Study of Dry Matter Yield, Forage Quality and Botanical Composition for Three Turf-type Mixtures
}

Joong Hae Lee*, In Duk Lee* and Hyung Suk Lee**

Division of animal science and resources, Chungnam National University*,

Woosong Information College**

\begin{abstract}
To examine the potentiality of grassland dominated with turf-type grasses, which are mainly used for the establishment of green spaces, forage production and its utilization as forage resources, dry matter yield and forage quality of three different turf-type mixtures were estimated throughout three consecutive experimental years.

According to the experiment, the mean of dry matter(DM) yield, chemical composition, DM digestibility, crude protein dry matter(CPDM) and digestible dry matter(DDM) yield was not significantly different among species $(\mathrm{p}>0.05)$ over three experimental years.

Botanical composition of three dominant species(tall fescue, Kentucky bluegrass and perennial ryegrass) was 42, 35 and 28\%, respectively, in three mixtures at the last cutting(6th) in 2001. The botanical composition of three dominated species such as tall fescue, Kentucky bluegrass and perennial ryegrass was maintained $84 \%$ of the total plants in all types of mixtures. Therefore, It is observed that the mixture types did not closely affect the botanical composition. But botanical composition of the other species such as redtop(8\%) and creeping bentgrass $(6 \sim$

$\sim \%)$ of all mixed species.

As mentioned above, any difference was not observed in DM yields, forage quality and botanical composition among mixture types. Therefore, any types of mixtures can be used as public green spaces like school ground areas or river-sides, and as forage resources additionally.
\end{abstract}

(Key words : Turf type mixtures, DM yield, Dry matter digestibility, Botanical composition)

$$
\text { I 서 론 }
$$

일반적으로 혼파는 단파에 비하여 공간이용 이 유리하고, 토양중의 수분과 양분의 이용효 율을 높여 수량과 품질 및 초지의 이용연한을 증가시킨다. 그러나, 조사료의 생산이 주목적인 지금까지의 관행 혼파조합(이 1972; 나 등, 1979; 신, 1979; 황 등, 1989)에 비하여 하번초
형 혼파조합은 공익적인 목적이 강조되는 하번 초형 잔디초지가 대부분이기 때문에 수량과 품 질도 중요하겠지만 밀도, 색상, 질감, 답압 및 병충해 저항성 등을 우선적으로 고려한 혼파조 합이 강조된다고 하겠다. 우리 나라에서도 하 번초형 잔디초지의 혼파조합으로 남방형으로는 한국잔디와 bermudagrass를, 북방형으로는 Kentucky bluegrass, perennial ryegrass 및 tall fescue

\footnotetext{
Corresponding author : In Duk Lee, Division of animal science and resources, College of agriculture and Life Science, Chungnam National University, Daejon 305-764, Korea. Tel : (042)821-5785, E-mail : lee46@cnu.ac.kr
} 
를 단파 또는 혼파하여 이용하고 있으며, 집 약적인 조성과 관리가 요구되는 전문적인 골프 장이나 축구장에서는 개량형의 들잔디를 단파 하거나, Kentucky bluegrass와 perennial ryegrass 를 단순 혼파하는 조합을 추천하고 있다(국민 체육진흥공단, 2002). 이와는 달리, 조방적인 조 성과 관리가 요구되는 학교나 공공기관의 운동 장이나 공원 및 하천변 등에 조성되고 있는 하 번초형 혼파조합은 남부지역의 경우, 한국잔디 와 bermudagrass를 중심으로, 기타지역에서는 Kentucky bluegrass, perennial ryegrass, tall fescue 를 단파 또는 혼파하여 이용하고 있는 실정이 다. 그러나, 골프장이나 축구장에서 생산되는 초류는 산업폐기물로 분류되어 이를 직접 양축 농가에서 조사료원으로 활용하기에는 어려움이 큰 실정이다. 그러나 학교와 공공기관 등에 조 성되어 관리되고 있는 하번초형 혼파초지(잔디 초지 포함)의 경우는 잔디초지로써 운동장 역 할은 물론이고 농업고등학교(청양, 공주)의 경 우는 생산되는 목초를 가축의 조사료원으로 활 용하고 있다. 그러나, 지금까지 하번초형 혼파 초지(잔디초지)에 대한 국내 연구는 많지 않고 다만, 골프장을 대상으로 안양소재 “한국잔디 연구소”에서 일부 연구가 수행되고 있을 뿐, 본 시험에서와 같이 공익목적과 부수적으로 생산 되는 목초를 조사료원으로 활용가능성을 탐색 하고자 하는 연구는 미진한 실정에 있다. 따라 서 본 시험에서는 국내 골프장이나 축구장과는 달리 국내에서 현재 조성되고 있는 turf-type의 초종을 공시하여 앞에서 언급한 2가지 목적을 얻을 수 있는 일련의 연구 중에서 하번초형 혼 파초지를 조성하기에 적합해 보이는 몇 가지 초종을 공시하여 지반조성이나 관리방법이 조 방적인 학교나 공공기관의 운동장을 하번초형 혼파초지로 전환하는데 적합한 혼파조합을 선 정하는 데 기초자료로 이용하고자 본 연구를 수행하였다.

\section{프재료 및 방법}

본 연구는 1998년 9월부터 2001년 12월까지 충남대학교 생명과학대학내 부속 초지시험포장
에서 수행하였다. 공시된 하번초형 혼파조합은 tall fescue 중심의 혼파조합\{tall fescue(Rebell Jr.) $40 \%+$ perennial ryegrass(Palmer П $20 \%+$ Kentucky bluegrass(Newport) $10 \%+$ redtop(Barricuda) $10 \%+$ red fescue(Salem) $10 \%+$ creeping bentgrass(Crenshaw) 10\%\}, Kentucky bluegrass 중심 의 혼파조합\{Kentucky bluegrass $40 \%+$ tall fescue $20 \%+$ perennial ryegrass $10 \%+$ redtop $10 \%+$ red fescue $10 \%+$ creeping bentgrass $10 \%\}$ 및 perennial ryegrass 중심의 혼파조합 \{perennial ryegrass $40 \%+$ Kentucky bluegrass $20 \%+$ tall fescue $10 \%+$ redtop $10 \%+$ red fescue $10 \%+$ creeping bentgrass $10 \%$ \} 등 3 처리를 두어 시험하였다. 파종시기는 1998년 9월 4일 이었으며, 경운초지조성방법으로 조성하였다. 파종량은 각각 $\mathrm{ha}$ 당 $30 \mathrm{~kg}$ 을 파종하였으며, 시 비기준은 파종당시의 기비로 $\mathrm{N} 60 \mathrm{~kg}+\mathrm{P}_{2} \mathrm{O}_{5}$ $200 \mathrm{~kg}+\mathrm{K}_{2} \mathrm{O} 70 \mathrm{~kg} / \mathrm{ha}$ 를 시용하였고, 조성 후의 연간 관리비료는 $\mathrm{N} 180 \mathrm{~kg}+\mathrm{P}_{2} \mathrm{O}_{5} 200 \mathrm{~kg}+\mathrm{K}_{2} \mathrm{O}$ $150 \mathrm{~kg} / \mathrm{ha}$ 을 1999년과 2000년에는 월동 후와 2, 4, 6 및 8회 예취 후에, 2001년에는 월동 후와 2회 및 4회 예취 후에 균등 분시하였다. 시험 구의 구당 면적은 $16 \mathrm{~m}^{2}$ 이었으며, 시험구 배치 는 난괴법 3 처리 4 반복으로 하였다. 건물수량 은 예취시 마다 조사한 생초수량에 건물률을 곱하여 산출하였다. 식생비율은 1999년과 2000 년에는 1회, 5 회 및 10회에, 2001년은 1회, 3회 및 6회 예취시에 각 초종별로 분류하여 건물중 기준으로 비율을 산출하였다. 1회 예취시기는 초고 15 3cm일 때, 2회 예취부터는 초고 12 $15 \mathrm{~cm}$ 일 때 예취하였으며, 예취횟수는 기상조 건과 생육상태에 따라 1999, 2000 및 2001년도 에 각각 10,10 및 6 회 예취하였다. 화학적 성 분을 분석하기 위한 시료는 1 회와 마지막 예취 시의 시료를 잘 섞어 분석용 시료로 준비하였 다. Crude protein(CP)은 AOAC(1995) 방법으로, neutral detergent fiber(NDF), acid detergent fiber (ADF) 및 lignin은 Goering과 Van Soest(1970) 방법으로, cellulose는 Crampton과 Maynard(1938) 방법으로 분석하였다. Hemicellulose는 NDF와 $\mathrm{ADF}$ 의 차이로 구하였다. In vitro dry matter digestibility(DMD)는 Tilley와 Terry(1963)의 방법 
년에는 85

1\%의 범위

를 보여 혼파조합간에 식생비율의 차이가 크지 않았을 뿐 아니라, 건물수량의 증감에 미치는 초종 개개의 영향보다는 혼파로 인한 초종의 상호 보완작용으로 인하여(脇木 1980 ; 이와 이, 1995) 혼파조합에 따른 건물수량의 차이가 크지 않았을 것으로 판단되며, 이와 이(2003)가 보고한 바와 같이 본 시험에 공시된 초종과 동 일한 하번초형의 tall fescue(11,439kg/ha), perennial ryegrass $(10,726 \mathrm{~kg} / \mathrm{ha})$ 및 Kentucky bluegrass $(10,331 \mathrm{~kg} / \mathrm{ha})$ 를 단파하여 시험하였던 결과에서 도 이들 3 초종간에 건물수량의 차이가 크지 않 았다고 보고되고 있어, 이들 3초종을 중심으로 혼파조합을 달리하여 시험하였던 본 시험의 결 과에서도 역시 건물수량의 차이가 크지 않았던 것으로 생각된다.

그러나, 하번초형(turf type) 초종들은 건물수 량도 중요하지만 질감, 피복도, 밀도, 색상, 내 병충성 등 하번초로서의 특성이 더 강조되는 초종이기 때문에(국민체육진흥공단, 2002), 이들 초종을 중심으로 혼파조합을 달리하였을 때 얻 어진 시험결과는 조사료생산이 주목적인 관행 혼파조합을 공시하여 얻어진 시험결과(이 1972; 나 등, 1979; 신, 1979; 황 등, 1989)와 비교할 때 차이가 있다고 하겠다. 더욱이, 국내에서 많 이 이용되고 있는 하번초형 혼파조합의 경우, 골프장은 Kentucky bluegrass + tall fescue + perennial ryegrass 조합이나 Kentucky bluegrass + chewing fescue조합 내지는 Kentucky bluegrass $+\mathrm{ll}$ fescue + perennial ryegrass + bermudagrass 의 조합을, 축구장에서는 한국잔디나 Kentucky bluegrass 및 perennial ryegrass를 단파하거나 혼 파하여 이용하고 있으며, Hessayon(2000)은 고 급 잔디초지(luxury lawn)의 경우, chewing fescue + browntop조합을, 실용적인 잔디초지(utility lawn)에서는 Kentucky bluegrass + creeping red fescue + chewing fescue + browntop 조합을 제 시하고 있어, 하번초형 혼파조합의 유형에 따 라서 건물수량의 차이가 충분히 나타날 수 있 을 것으로 사료된다. 따라서, 하번초형 혼파초 지를 조성하기 위한 적정 혼파조합의 선정은 매우 중요하다고 하겠으며, 이에 대해서는 김
(1983)도 지역특성, 조성 및 관리방법과 이용목 적에 따른 혼파조합의 중요성을 강조한 바 있 다. 그러나, 본 시험결과에서는 위에서 언급한 바와 같이 건물수량의 증감에 미치는 혼파조합 의 영향이 크게 나타나지 않았던 것으로 보아, 본 시험에서와 같이 조방적인 방법으로 공익목 적과 부수적으로 생산되는 목초를 조사료원으 로 활용하기 위해 조성되는 하번초형 혼파초지 의 경우는 tall fescue, Kentucky bluegrass 및 perennial ryegrass 중심의 어느 혼파조합을 추천 하여도 무난할 것으로 판단된다. 다만, 조성 후 에도 초지를 지속적으로 유지 및 관리하기 위 해서는 환경적응성과 답압에 강한 bentgrass나 redtop과 같은 초종들을 같이 혼파 해주는 것 이, 골프장이나 축구장과 같이 1 개 초종만 을 혼파하여 전문적으로 조성 및 관리하는 혼 파방법보다, 앞에서 언급한 두 가지 목적을 얻 을 수 있는 하나의 방법이라 하겠다.

\section{2. 화학적 성분 및 건물소화율}

화학적 성분과 건물소화율을 조사한 결과는 Table 2에서 보는 바와 같다. 대체적으로 조사 연도(1999 )01)에 관계없이 tall fescue, Kentucky bluegrass 및 perennial ryegrass 중심의 혼 파조합 간에 crude protein(CP), hemi-cellulose, cellulose 및 lignin 함량의 차이는 크지 않았고, 3 년 평균성적도 혼파조합간에 큰 차이를 나타 내지 않았다. 그러나, $\mathrm{NDF}$ 와 $\mathrm{ADF}$ 함량은 2000 년도에 perennial ryegrass 중심의 혼파초지에서 다소 낮은 결과를 나타내었을 뿐, 연도에 관계 없이 혼파조합에 따른 뚜렷한 차이는 없었다. dry matter digestibility(DMD)는 1999년도와 2000 년도에 perennial ryegrass 중심의 혼파초지에 서 다소 높은 결과를 보이고 있으나 $(\mathrm{p}<0.05)$, 2001년과 3년 평균 $\mathrm{DMD}$ 는 혼파조합간에 뚜렷 한 차이를 보이지 않았다. 물론, 축산기술연구 소(2002)의 한국사료성분표에 나타난 사초용 tall fescue, perennial ryegrass 및 Kentucky bluegrass의 일반 화학적 성분이나, 이 등(2003)이 하번초형 초종을 공시하여 얻었던 화학적 성분 과 $\mathrm{DMD}$ 의 시험결과와 비교해 볼 때, 본 시험 
Table 2. Chemical composition of the herbages harvested from three different turf-type mixed swards throughout three experimental years

\begin{tabular}{|c|c|c|c|c|c|c|c|c|}
\hline Year & Mixtures & $\mathrm{CP}$ & $\mathrm{NDF}$ & $\mathrm{ADF}$ & Hemicell-ulose & Cellulose & Lignin & DMD \\
\hline \multirow{5}{*}{1999} & & …..... & n....... & ......... & $\cdots . \overline{\mathrm{DM}}, \% \cdot \cdots$ & ….............. & ............ & ........... \\
\hline & TF & $18.8^{\mathrm{a}}$ & $58.9^{\mathrm{a}}$ & $30.7^{\mathrm{a}}$ & $28.2^{\mathrm{a}}$ & $27.1^{\mathrm{a}}$ & $6.3^{\mathrm{a}}$ & $77.3^{\mathrm{b}}$ \\
\hline & $\mathrm{KB}$ & $19.0^{\mathrm{a}}$ & $60.1^{\mathrm{a}}$ & $29.6^{\mathrm{a}}$ & $30.5^{\mathrm{a}}$ & $27.2^{\mathrm{a}}$ & $6.8^{\mathrm{a}}$ & $77.7^{\mathrm{b}}$ \\
\hline & PR & $19.1^{\mathrm{a}}$ & $56.2^{\mathrm{a}}$ & $30.1^{\mathrm{a}}$ & $26.1^{\mathrm{a}}$ & $26.2^{\mathrm{a}}$ & $6.5^{\mathrm{a}}$ & $79.2^{\mathrm{a}}$ \\
\hline & Mean & 19.0 & 58.4 & 30.1 & 28.3 & 26.8 & 6.5 & 78.1 \\
\hline \multirow{4}{*}{2000} & $\mathrm{TF}$ & $18.8^{\mathrm{a}}$ & $61.6^{\mathrm{a}}$ & $31.1^{\mathrm{a}}$ & $31.3^{\mathrm{a}}$ & $26.5^{\mathrm{a}}$ & $6.2^{\mathrm{a}}$ & $77.1^{\mathrm{C}}$ \\
\hline & KB & $18.0^{\mathrm{a}}$ & $61.4^{\mathrm{a}}$ & $30.6^{\mathrm{b}}$ & $30.8^{\mathrm{a}}$ & $27.2^{\mathrm{a}}$ & $6.1^{\mathrm{a}}$ & $77.4^{\mathrm{b}}$ \\
\hline & PR & $18.6^{\mathrm{a}}$ & $60.9^{b}$ & $30.4^{\mathrm{b}}$ & $30.5^{\mathrm{a}}$ & $26.2^{\mathrm{a}}$ & $5.7^{\mathrm{a}}$ & $77.7^{\mathrm{a}}$ \\
\hline & Mean & 18.5 & 61.3 & 30.7 & 30.9 & 26.6 & 6.0 & 77.4 \\
\hline \multirow{4}{*}{2001} & $\mathrm{TF}$ & $15.0^{\mathrm{a}}$ & $62.8^{\mathrm{a}}$ & $31.5^{\mathrm{a}}$ & $31.3^{\mathrm{a}}$ & $26.6^{\mathrm{a}}$ & $4.6^{\mathrm{a}}$ & $77.1^{\mathrm{a}}$ \\
\hline & $\mathrm{KB}$ & $16.1^{\mathrm{a}}$ & $62.0^{\mathrm{a}}$ & $33.3^{\mathrm{a}}$ & $28.7^{\mathrm{a}}$ & $28.0^{\mathrm{a}}$ & $3.9^{\mathrm{a}}$ & $76.7^{\mathrm{a}}$ \\
\hline & PR & $16.1^{\mathrm{a}}$ & $63.3^{\mathrm{a}}$ & $33.2^{\mathrm{a}}$ & $38.1^{\mathrm{a}}$ & $27.7^{\mathrm{a}}$ & $3.9^{\mathrm{a}}$ & $76.0^{\mathrm{a}}$ \\
\hline & Mean & 15.7 & 62.7 & 32.7 & 32.7 & 27.4 & 4.1 & 76.6 \\
\hline \multirow{3}{*}{$\begin{array}{l}\text { Year } \\
\text { mean }\end{array}$} & $\mathrm{TF}$ & $17.5^{\mathrm{a}}$ & $61.1^{\mathrm{a}}$ & $31.1^{\mathrm{a}}$ & $30.0^{\mathrm{a}}$ & $26.7^{\mathrm{a}}$ & $5.7^{\mathrm{a}}$ & $77.2^{\mathrm{a}}$ \\
\hline & KB & $17.7^{\mathrm{a}}$ & $61.2^{\mathrm{a}}$ & $31.2^{\mathrm{a}}$ & $30.0^{\mathrm{a}}$ & $27.5^{\mathrm{a}}$ & $5.6^{\mathrm{a}}$ & $77.3^{\mathrm{a}}$ \\
\hline & PR & $17.9^{\mathrm{a}}$ & $60.1^{\mathrm{a}}$ & $31.2^{\mathrm{a}}$ & $28.9^{\mathrm{a}}$ & $26.7^{\mathrm{a}}$ & $5.4^{\mathrm{a}}$ & $77.6^{\mathrm{a}}$ \\
\hline
\end{tabular}

CP; Crude protein, NDF; Neutral detergent fiber, ADF; Acid detergent fiber, DMD; Dry matter digestibility.

${ }^{a, b, c}$ Means in the same column with different letters were significantly different $(\mathrm{p}<0.05)$.

에서 얻어진 결과와는 다소 차이를 보이고 있

다고 하겠으나, 이는 공시 초종이나 혼파조합 과 같은 시험조건의 차이에서 기인된 것이라 하겠다. 한편, 본 시험결과에서 얻어진 화학적 성분과 $\mathrm{DMD}$ 가 혼파조합에 따라 큰 차이를 보 이지 않았던 것은 Table 4에서 보는 바와 같이 tall fescue, Kentucky bluegrass 및 perennial ryegrass 중심의 혼파조합에서 얻어진 주요 초종의 식생비율 합계가 큰 차이를 보이지 않았기 때 문에 얻어진 결과로 해석된다.

\section{3. 조단백질 및 가소화건물 수량}

조단백질 건물(crude protein dry matter, CPDM) 수량과 가소화건물(digestible dry matter, DDM) 수량을 조사한 결과는 Table 3과 같다. ha당 $\mathrm{CPDM}$ 수량은, 1999년과 2000년에는 혼파조합 간에 큰 차이가 없었으나, 2001년에는 Kentucky bluegrass 중심의 혼파조합이 $1,524 \mathrm{~kg}$ 으로 tall fescue $(1,464 \mathrm{~kg})$ 나 perennial ryegrass $(1,408 \mathrm{~kg})$ 중 심의 혼파조합에 비하여 높은 결과를 보였으 나(p<0.05), 3년 평균 ha당 CPDM 수량은 혼파

Table 3. Crude protein dry matter(CPDM) and digestible dry matter(DDM) yields in three different turf-type mixed swards for three experimental years

\begin{tabular}{|c|c|c|c|c|c|c|c|c|}
\hline \multirow{2}{*}{ Mixtures } & \multicolumn{4}{|c|}{ CPDM } & \multicolumn{4}{|c|}{ DDM } \\
\hline & 1999 & 2000 & 2001 & Year mean & 1999 & 2000 & 2001 & Year mean \\
\hline & & & & - & 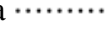 & 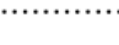 & ....... & $\cdots \cdot$ \\
\hline $\mathrm{TF}$ & $2,309^{\mathrm{a}}$ & $2,576^{a}$ & $1,464^{\mathrm{b}}$ & $2,116^{\mathrm{a}}$ & $9,386^{\mathrm{a}}$ & $10,540^{\mathrm{a}}$ & $7,521^{\mathrm{a}}$ & $9,149^{\mathrm{a}}$ \\
\hline $\mathrm{KB}$ & $2,319^{\mathrm{a}}$ & $2,532^{\mathrm{a}}$ & $1,524^{\mathrm{a}}$ & $2,125^{\mathrm{a}}$ & $9,563^{\mathrm{a}}$ & $10,861^{\mathrm{a}}$ & $7,265^{\mathrm{b}}$ & $9,230^{\mathrm{a}}$ \\
\hline PR & $2,307^{\mathrm{a}}$ & $2,508^{a}$ & $1,408^{\mathrm{C}}$ & $2,074^{\mathrm{a}}$ & $9,596^{\mathrm{a}}$ & $10,498^{\mathrm{a}}$ & $6,649^{c}$ & $8,914^{\mathrm{a}}$ \\
\hline
\end{tabular}

CPDM; Crude protein dry matter, DDM; Digestible dry matter.

${ }^{a, b, c}$ Means in the same column with different letters were significantly different $(\mathrm{p}<0.05)$. 
조합에 따라 뚜렷한 차이는 나타나지 않았다.

한편, ha당 DDM 수량은 1999년과 2000년의 경우, 혼파조합간에 뚜렷한 차이를 보이지 않 았다. 그러나, 2001년에는 Table 1과 2에서 보 는 바와 같이 건물수량과 건물소화율이 다른 혼파조합에 비하여 상대적으로 높았던 tall fescue 중심의 혼파조합이 다른 혼파조합에 비 하여 $\mathrm{DDM}$ 수량이 더 높은 결과를 가져왔으 나(p<0.05), 역시 3년 평균 $\mathrm{DDM}$ 수량은 혼파 조합에 따라 뚜렷한 차이를 보이지 않았다. 이 러한 결과는 Table 1과 2에서 보는 바와 같이 혼파조합에 따른 건물수량과 $\mathrm{DDM}$ 의 차이가 크지 않았기 때문에 얻어진 결과라 하겠다.

\section{4. 식생변화}

혼파조합별로 조사한 1회, 5회 및 10회 예취 시에 조사한 식생비율은 Table 4에서 보는 바 와 같다. 1999년도에는 예취횟수가 경과함에 따라, 일관된 경향은 아니었지만 대체적으로 혼파조합에 관계없이 tall fescue는 증가한 반면 에, Kentucky bluegrass와 perennial ryegrass의 식 생비율은 감소되는 양상을 보였다. 따라서, 10 회 마지막 예취시 tall fescue, Kentucky bluegrass 및 perennial ryegrass 중심의 혼파조합에서 중심초종인 tall fescue, Kentucky bluegrass 및 perennial ryegrass의 식생비율은 각각 40, 33 및 $35 \%$ 으로 높은 편이었고, 각 혼파조합별로 조사 한 전체 초종에서 이들 3 초종이 차지하는 식생 비율은 각각 84,87 및 $87 \%$ 를 나타나 이들 초 종들이 우점된 반면에, 기타 초종들의 식생비 율은 13 $3 \%$ 으로 낮은 결과를 보였다. 기타 초종중에서는 $\operatorname{redtop}(6$ \%)의 식생비율이 높은 편이었으나, 나머지 초종들의 식생비율은 $5 \%$ 이하로 낮은 편이었다.

2000년도에는 1999년과 마찬가지로 예취횟수 가 경과함에 따라, 일관된 경향은 아니었지만 대체적으로 혼파조합에 관계없이 tall fescue와 Kentucky bluegrass의 식생비율은 증가한 반면 에, perennial ryegrass의 식생비율은 감소되는 경향이었다. 따라서 10회 마지막 예취시 tall fescue, Kentucky bluegrass 및 perennial ryegrass 중심의 혼파조합에서 중심초종인 tall fescue, Kentucky bluegrass 및 perennial ryegrass의 식생 비율은 각각 45, 35 및 35\%으로 높은 편이였으 며, 각 혼파조합별로 조사한 전체 초종에서 이 들 3 초종이 차지하는 식생비율은 각각 85,90 및 90\%로 1999년보다 증가되었다. 그러나, 기 타 초종들의 식생비율은 $10 \sim 5 \%$ 으로 감소되 는 양상을 보였다. 기타 초종중에서는 redtop (5 \%)의 식생비율이 높은 편이었고, 나머지 초종들의 식생비율은 $5 \%$ 이하를 유지하는데

Table 4. Effect of mixture types on botanical composition(\%) in turf type mixtures

\begin{tabular}{|c|c|c|c|c|c|c|c|c|c|c|c|c|c|c|c|c|c|c|c|}
\hline \multirow{2}{*}{ Year } & \multirow{2}{*}{ Mixtures } & \multicolumn{6}{|c|}{ 1st cut } & \multicolumn{6}{|c|}{ 5th cut $^{1)}$} & \multicolumn{6}{|c|}{ 10th cut $^{2)}$} \\
\hline & & $\mathrm{TF}$ & PR & $\mathrm{KB}$ & $\mathrm{RT}$ & $\mathrm{RF}$ & $\mathrm{CB}$ & $\mathrm{TF}$ & PR & $\mathrm{KB}$ & RT & $\mathrm{RF}$ & $\mathrm{CB}$ & $\mathrm{TF}$ & PR & $\mathrm{KB}$ & RT & RF & CB \\
\hline \multirow{3}{*}{1999} & $\mathrm{TF}$ & 32 & 43 & 9 & 6 & 7 & 3 & 34 & 41 & 8 & 7 & 7 & 3 & 40 & 32 & 12 & 7 & 5 & 4 \\
\hline & KB & 28 & 15 & 43 & 7 & 4 & 3 & 35 & 24 & 29 & 6 & 4 & 2 & 31 & 23 & 33 & 6 & 5 & 2 \\
\hline & PR & 23 & 39 & 25 & 5 & 5 & 3 & 26 & 43 & 24 & 4 & 3 & + & 30 & 35 & 22 & 6 & 4 & 3 \\
\hline \multirow{3}{*}{2000} & $\mathrm{TF}$ & 38 & 30 & 13 & 8 & 5 & 6 & 48 & 28 & 13 & 7 & 4 & 0 & 45 & 23 & 17 & 7 & 3 & 5 \\
\hline & $\mathrm{KB}$ & 33 & 28 & 28 & 6 & 4 & 1 & 31 & 25 & 35 & 5 & 3 & 1 & 35 & 20 & 35 & 5 & 3 & 2 \\
\hline & PR & 33 & 40 & 14 & 6 & 4 & 3 & 30 & 35 & 29 & 4 & 1 & 1 & 35 & 35 & 20 & 6 & 4 & 0 \\
\hline \multirow{3}{*}{2001} & $\mathrm{TF}$ & 37 & 21 & 28 & 5 & 4 & 5 & 40 & 20 & 27 & 6 & 3 & 4 & 42 & 18 & 24 & 8 & 2 & 6 \\
\hline & KB & 30 & 25 & 37 & 4 & 2 & 2 & 30 & 15 & 35 & 10 & 5 & 5 & 31 & 18 & 35 & 8 & 1 & 7 \\
\hline & PR & 30 & 40 & 19 & 5 & 3 & 3 & 30 & 35 & 20 & 10 & 3 & 2 & 36 & 28 & 20 & 8 & 2 & 6 \\
\hline
\end{tabular}

1) 3rd cut in 2001, ${ }^{2)}$ 6th cut in 2001.

TF; Tall fescue, PR; Perennial ryegrass, KB; Kentucky bluegrass, RT; Redtop, RF; Red fescue, CB; Creeping bentgrass. 
그쳤다. 2001년도에도 예취횟수가 경과함에 따 라, 일관된 경향은 아니지만 대체적으로 혼파 조합에 관계없이 tall fescue의 식생비율은 증가 하였고, Kentucky bluegrass는 약간 감소하였으 나, perennial ryegrass의 식생비율은 약간 증가 하는 경향을 나타내었다.

2001년도 6회 마지막 예취시 tall fescue, Kentucky bluegrass 및 perennial ryegrass 중심의 혼 파조합에서 중심초종인 tall fescue, Kentucky bluegrass 및 perennial ryegrass의 식생비율은 각 각 42, 35 및 $28 \%$ 으로 높은 편이었다. 한편, 각 혼파조합별로 조사한 전체 초종에서 이들 3 초 종이 차지하는 식생비율은 모든 혼파조합에서 $84 \%$ 로 나타나 혼파조합에 따른 식생비율의 차 이는 나타나지 않았다. 그러나, 기타 초종들의 식생비율의 합계는 $16 \%$ 으로, redtop(8\%)과 creeping bentgrass(6 \%)의 식생비율이 그 중에서도 높은 편이었으나 red fescue의 식생비율은 $2 \%$ 이 하로 매우 낮은 결과를 보였다.

이상의 시험결과를 종합해 볼 때, tall fescue, Kentucky bluegrass 및 perennial ryegrass 중심의 하번초형 혼파조합간에 건물수량, 화학적 성분 과 건물소화율 및 영양소 수량의 차이는 크지 않은 것으로 나타났다. 따라서, 공익목적의 학 교나 관공서 등의 운동장이나 하천 변 등에 조 방적인 방법으로 조성 및 관리가 요구되는 하 번초형 혼파초지의 경우, 부수적으로 생산되는 목초를 가축의 조사료원으로 활용하기 위한 하 번초형 혼파초지는 tall fescue, Kentucky bluegrass 및 perennial ryegrass를 중심으로 한 어느 혼파조합으로 조성하여도 무난할 것으로 사료 된다.

\section{IV 요 약}

본 시험은 혼파조합이 하번초형 혼파초지의 건물수량과 사료가치에 미치는 영향을 구명하 여 하번초형 혼파초지를 조성하는데 적합한 혼 파조합을 찾고자 1998년 9월부터 2001년 12월 까지 충남대학교 생명과학대학내 부속 초지시 험포장에서 수행하였다. 공시 혼파조합은 tall fescue, Kentucky bluegrass 및 perennial ryegrass
중심의 3 가지 혼파조합을 공시하였으며 얻어진 시험결과는 다음과 같다

1) 3 년 평균 $\mathrm{ha}$ 당 건물수량, 일반화학적 성 분, 건물소화율과 조단백질수량(CPDM) 및 가 소화건물수량 $(\mathrm{DDM})$ 은 혼파조합간에 차이가 없 었다.

2) 2001년도 6회 마지막 예취시 tall fescue, Kentucky bluegrass 및 perennial ryegrass 중심의 혼파조합에서 tall fescue, Kentucky bluegrass 및 perennial ryegrass의 식생 비율은 각각 42, 35 및 $28 \%$ 이었고, 전체 초종에서 이들 3 초종이 차 지하는 식생 비율은 모든 혼파조합에서 $84 \%$ 로 나타나 혼파조합이 식생비율에 미치는 영향은 크지 않았다. 기타 초종 중에서는 redtop(8\%)과 creeping bentgrass(6 \%)의 식생비율이 낮았으 며, 특히 red fescue(1 \%)는 매우 낮은 식생비 율을 보였다.

이상의 결과를 종합해 볼 때, 혼파조합간에 건물수량과 사료가치 및 식생비율에 뚜렷한 차 이가 없었던 것으로 보아, tall fescue, Kentucky bluegrass 및 perennial ryegrass 중심의 어느 혼 파조합으로 하번초형 혼파초지를 조성하여도 공익목적과 부수적으로 생산되는 목초를 조사 료원으로 활용가능성은 크다고 하겠다.

\section{$\mathrm{V}$ 인 용 문 헌}

1. AOAC. 1995. Official method of analysis(16th ed.) Association of Official Analytical Chemists. Washington, DC.

2. Crampton, F. W. and Maynard, L. A. 1938. The relation of cellulose and lignin content to the nutritive value of animal feeds. J. Nut. 15:383-395.

3. Goring, H. K. and Van Soest, P. J. 1970. Forage fiber analysis. Agr. Handbook. No. 379. ARS. USDA. Washington, DC.

4. Hessayon, D. J. 2000. The lawn expert. Transworld publishers LTD. London. England.

5. Tilley, J. A. M. and Terry, R. A. 1963. A two stage technique for in vitro digestibility of forage crops. J. Brit. Grassl. Sci. 18:104-111.

6. 脇本隆混播牧草の に方る明 究 北海道農試㸴報 30:1-80.

7. 김내수, 김정우, 박홍양, 상병찬, 여정수, 전광주, 최광수, 홍기창. 1995. 응용통계학. 유한문화사. 서울. 
8. 김동암. 1983. 산지초지개발의 기술적 과제. 한 국농촌경제연구원. 서울. pp. 140-196.

9. 국민체육진흥공단. 2002. 녹색 천연잔디 운동장 의 조성과 관리. 애디플러스. 서울. pp. 73-94.

10. 나기준, 이근상, 황석중, 백윤기, 고서봉, 진신흠, 정창조. 1979. 제주지방에 있어서 목초의 혼파조 합 선발에 관한 연구. 농시연보. 21:111-123.

11. 신기준. 1979. 혼파조합 선발시험. 농시연보. 21: 40-45.

12. 이광직. 1972. 지역별 영구 목야지조성을 위한 혼파조합 선발시험. 축시연보. pp. 499-522.
13. 이인덕, 이형석. 2003. 상번초 및 상 - 번초형 혼파초지의 건물수량 및 사료가치 비교 연구. 한 초지. 23(2):121-128.

14. 이형석, 이인덕. 1995. Orchardgrass단파, red clover 단파 및 orchardgrass - red clover 단순혼파 목초 의 경쟁구조 해석. 한초지. 15(4):279-284.

15. 축산기술연구소. 2002. 한국표준사료성분표. 문영 당. 수원. pp. 386-437.

16. 황석중, 임영철, 최선식. 1989. 지대별, 표고별 목 초 혼파조합 선발시험. 축시연보. pp. 373-396.

(접수일자 : 2004. 3. 11. / 채택일자 : 2004. 5. 11.) 